\title{
Shrub-induced snowpack variability alters wintertime soil respiration across a simulated tundra landscape
}

\author{
Daniel Ackerman (1D \\ Department of Ecology, Evolution, and Behavior, University of Minnesota, St Paul, MN, USA
}

\begin{abstract}
Across the arctic tundra, the expansion of tall shrubs is expected to alter soil microbial activity in winter through shrub effects on snow redistribution. Tall shrubs act as a windbreak, trapping deep snowdrifts that insulate the ground from extreme cold and elevate soil respiration within shrub patches. However, this windbreak effect may reduce both snow cover and soil respiration in open tundra areas outside shrub patches. The net impact of increasing shrub cover on soil respiration across landscapes with heterogeneous vegetation cover and snow depths remains unknown. Here, I use a set of tundra landscape simulations to address this knowledge gap. The simulations vary shrub cover, mean snow depth and the strength of shrub windbreak effect. I show that for mean snowfall depths $40 \mathrm{~cm}$ or greater, increasing shrub cover usually reduced landscape-level soil respiration due to greater heterogeneity in snow depth. These simulations suggest that there is no overarching positive relationship between shrub density and wintertime soil respiration on a landscape scale. Hypotheses generated from these simulations may be tested empirically to improve the representation of tundra vegetation and snow dynamics in Earth System Models.
\end{abstract}

\section{KEYWORDS}

Arctic; carbon cycle; shrub expansion; snow; winter ecology; soil respiration

\section{Introduction}

Despite extremely cold temperatures, the lengthy winter season contributes significantly to annual carbon and nutrient cycling in Arctic tundra, where nearly half of Earth's terrestrial organic carbon is stored (Hobbie \& Chapin 1996; Fahnestock et al. 1999; Tarnocai et al. 2009; Hugelius et al. 2014; Oechel et al. 2014). Across space, rates of wintertime elemental cycles are tightly linked to snow depth. Snow insulates soils from low air temperatures and allows microbial activity such as heterotrophic respiration to continue throughout the winter (Walker et al. 1999; Taras et al. 2002; Nobrega \& Grogan 2007). For example, Fahnestock et al. (1999) estimate that in the tundra of northern Alaska between 47 and $400 \mathrm{~kg} \mathrm{CO} \mathrm{ha}^{-1}$ are released annually from snow-covered soils. The insulation capacity of snow is determined by a suite of factors, including density and phase change dynamics, but insulation generally increases with snow depth (Stieglitz et al. 2001; Ge \& Gong 2010).

Tall shrubs exert many biotic and abiotic controls on their environment via their effects on litter chemistry, soil decomposer communities, albedo, moisture and temperature throughout the year (Myers-Smith \& Hik 2013; Bueno et al. 2016). In winter, tall shrubs form windbreaks by jutting above the low-statured vegetation of the Arctic tundra. This windbreak effect redistributes blowing snow from non-shrubby areas to shrubby areas (Liston et al. 2002). Consequently, deep, insulating snowdrifts preferentially accumulate on and immediately leeward of shrub patches, increasing winter soil temperatures (Sturm et al. 2001). It is thought that these elevated temperatures will accelerate microbial processes such as nitrogen mineralization and soil respiration in shrub patches (Sturm et al. 2001, 2005; Schimel et al. 2004; Grogan \& Jonasson 2006; Baptist et al. 2010; Hallinger et al. 2010; Morgner et al. 2010; Rogers et al. 2011; Blok et al. 2016; Paradis et al. 2016). This situation may be reversed in nearby non-shrubby patches, where reduced snow depth leads to lower soil temperatures.

Within the tundra biome, tall shrubs are increasing in areal cover and biomass, and are expanding to new areas, including up altitudinal gradients (Tape et al. 2006; Hallinger et al. 2010; Myers-Smith et al. 2011). As shrubs continue to proliferate in the tundra landscape, greater heterogeneity of snowpack depth (and therefore of wintertime soil respiration) should be expected (Liston et al. 2002). However, most experimental studies connecting shrub expansion to soil microbial activity examine shrub presence/ absence instead of variable levels of shrub cover (e.g., Nauta et al. 2015). Such research also tends to use small plot sizes, on the order of $1 \mathrm{~m}^{2}$, which are

CONTACT Daniel Ackerman dackerma@umn.edu E Department of Ecology, Evolution, and Behavior, University of Minnesota, 140 Gortner Laboratory, 1470 Gortner Avenue, St Paul, MN 55108, USA 
not sufficient to capture the effects of shrub patches on nearby non-shrubby areas (e.g., Natali et al. 2012). Therefore, the overall landscape-level effect of shrub expansion on cold season soil respiration remains unknown.

Here I construct a set of simulations to explore potential impacts of shrub expansion on wintertime soil respiration across the tundra landscape, taking into account areas without shrub cover. I present a range of possible landscape-level outcomes of respiration for different combinations of shrub density, snow depth, and strength of the aforementioned windbreak effect. With this study I aim to answer the following questions. What is the relationship between shrub cover and wintertime soil respiration across the tundra landscape? How is this relationship changed by modifying mean snow depth and strength of the tall shrub windbreak effect?

By using simulations to answer these research questions, I hope to create clearly structured ideas about the interaction between snow, shrubs and soil respiration. These ideas may yield hypotheses that are empirically testable in the field.

\section{Methods}

I created a set of theoretical simulations to evaluate the effects of shrub expansion on landscape-level soil respiration in winter. The Northern Brooks Range Foothills region of Alaska was selected as the example system because ample data from this region are available to parameterize the key processes that comprise the simulations (e.g., Mikan et al. 2002; Zhang 2005; Tape et al. 2006; Stuefer et al. 2012). Processes used in the simulations were the windbreak effect of shrubs on snow accumulation, snow insulation effects on soil temperature, and temperature impacts on soil respiration. To explore the interaction of these processes across a wide range of conditions, I altered shrub density, the strength of the windbreak effect, and total snowfall across simulation runs. The simulations were run in $\mathrm{R}$ ( $\mathrm{R}$ Core Team 2016).

Each simulation consisted of a square $10000-$ pixel landscape grid (100 by 100 pixels), with each pixel representing a vegetation patch that was either open tussock tundra (i.e., graminoid) or shrub. Graminoid and shrub tundra classes collectively comprise two-thirds of the vegetated area in the Arctic (Walker et al. 2005). Shrub patches were distributed randomly across the landscape, with shrub cover varying between $0 \%$ and $30 \%$ to roughly match the observed range in shrub cover in the Northern Brooks Range Foothills between about 1950 and 2005 (Tape et al. 2006).

Next, snow was distributed across the vegetated landscape, ranging in average depth from 0.1 to $1 \mathrm{~m}$, a range centred on average end-of-winter snow depth for the Northern Brooks Range Foothills (Stuefer et al. 2012). Because of the windbreak effect of tall shrubs, snow preferentially accumulated in pixels representing shrub patches and, to a lesser extent, in pixels in the lee of shrub patches. The simulations assumed a consistent prevailing westerly wind. The simulations were run for three different levels of the windbreak effect, as specified by coefficients multiplying landscape-averaged snowfall by 1.5 (weak windbreak effect), 1.75 (moderate) or 2 times (strong), to define snow depth in shrub patches (Fig. 1). Measured windbreak coefficients are positively related to shrub height (Essery \& Pomeroy 2004; Paradis et al. 2016).

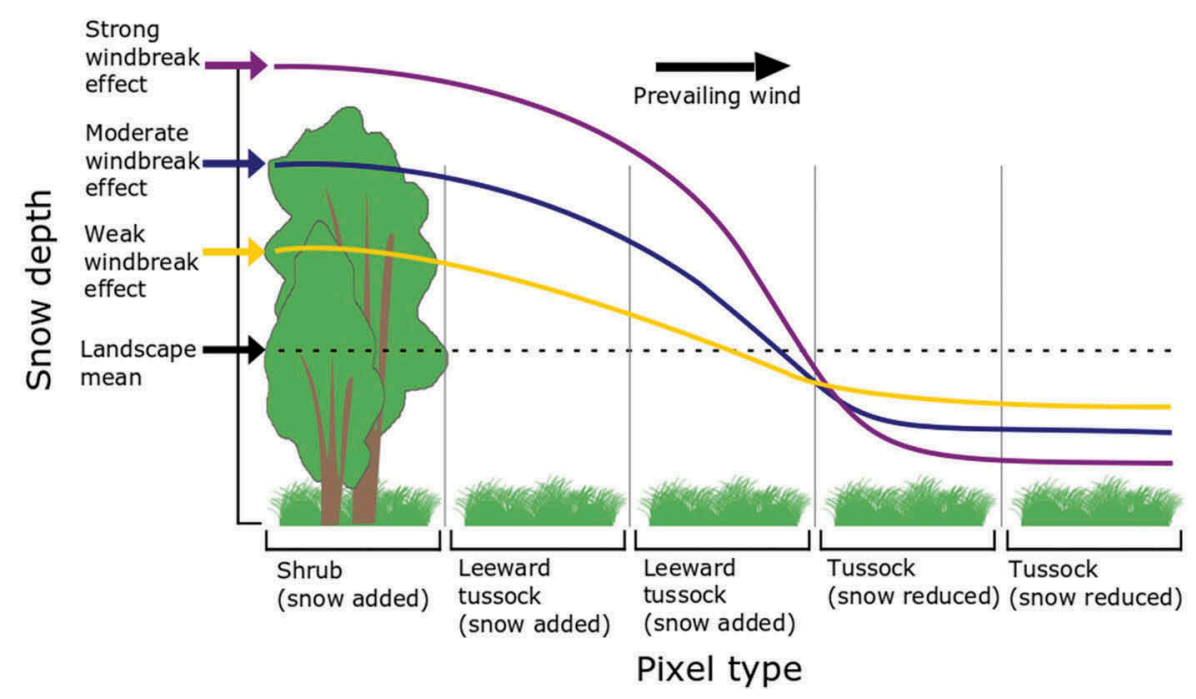

Figure 1. Shrub effects on relative snow depth in five linear pixels within the 10000-pixel simulated landscape. Snow preferentially accumulates in shrub patches and to a lesser extent in the two leeward tussock patches. Consequently, tussock patches further from shrub patches accumulate less snow than the landscape mean. Exact snow-depth quantities depend on the strength of the windbreak effect, which is empirically related to shrub height. In addition to the windbreak effect shown here, the simulation also varies the density of shrub pixels and mean snow depth across the landscape. 
On the basis of the distribution of snow across the simulated landscape, empirically derived relationships were used to calculate ground temperature and soil respiration rate for each pixel. Ground temperature is empirically determined by both air temperature and snow depth. For the simulation, air temperature was assumed to be constant, and the relationship between snow depth and ground temperature was parameterized using data collected in the Northern Brooks Range Foothills as reported by Zhang (2005; figure 10). These ground temperatures were used to calculate respiration rates using equations provided by Mikan et al. (2002, table 1), which include separate parameterizations for shrub and tussock soils in this region. These equations calculate respiration rates in units of respired carbon per mass of soil carbon, thus controlling for variability in soil carbon richness. Parameterized equations from Zhang (2005) and Mikan et al. (2002) are reproduced in the supplemental material.

Respiration rates were summed across all pixels to determine soil respiration across the entire theoretical landscape. Overall, 450 simulations of the 10000-pixel landscape were run for unique combinations of shrub density, mean snow depth and strength of the windbreak effect.

\section{Results}

Greater shrub cover did not always increase soil respiration across the landscape (Fig. 2). When mean snow depth was $10 \mathrm{~cm}$, respiration was negligible, regardless of shrub cover or the strength of the windbreak effect. When mean snow depth was $20-40 \mathrm{~cm}$, respiration generally increased with shrub cover, and the rate of increase was positively related to the strength of the windbreak effect.

For mean snow depths greater than $40 \mathrm{~cm}$, adding shrubs to an open tussock-tundra landscape initially reduced soil respiration until a threshold shrub coverage was reached. The strength of this reduction in respiration depended on the level of the windbreak effect and was greatest for the strong windbreak effect. The shrub cover threshold where respiration began to increase was also greater with increasing windbreak strength and was about $20 \%$ shrub cover for the strong windbreak effect. For mean snow depths less than $40 \mathrm{~cm}$, increased shrub density consistently elevated landscape soil respiration, regardless of the windbreak effect.

Across all 450 simulation runs, landscape-level soil respiration was maximized when shrub cover was $0 \%$, under the scenario with the greatest mean snowfall. Notably, the minimum soil respiration level was also achieved when shrub cover was $0 \%$, under the scenario with the least mean snowfall (Fig. 2).

\section{Discussion}

I ran a set of simulations to understand the relationship between shrub cover and wintertime soil respiration across the tundra landscape, and to determine how this relationship changes by varying mean snow depth and the strength of the windbreak effect. These simulations showed no unidirectional relationship between shrub cover and wintertime soil respiration on a landscape scale, in contrast to prior reports of soil microbial activity in individual shrubs patches (Sturm et al. 2001; Schimel et al. 2004; Sturm et al. 2005; Grogan \& Jonasson 2006; Baptist et al. 2010; Hallinger et al. 2010; Morgner et al. 2010; Rogers et al. 2011; Blok et al. 2016; Paradis et al. 2016). Rather, the relationship between shrub cover and soil respiration depended strongly on mean snow depth and the strength of the windbreak effect.

For snow depths greater than $40 \mathrm{~cm}$, increasing shrub cover up to about $20 \%$ reduced wintertime soil respiration across the landscape. This effect was especially pronounced for a strong windbreak effect. Because windbreak effect is empirically related to shrub height (Essery \& Pomeroy 2004), these simulations indicate that, in addition to shrub cover, shrub height impacts landscape-scale soil respiration. Notably, mean snow depth may be a stronger control
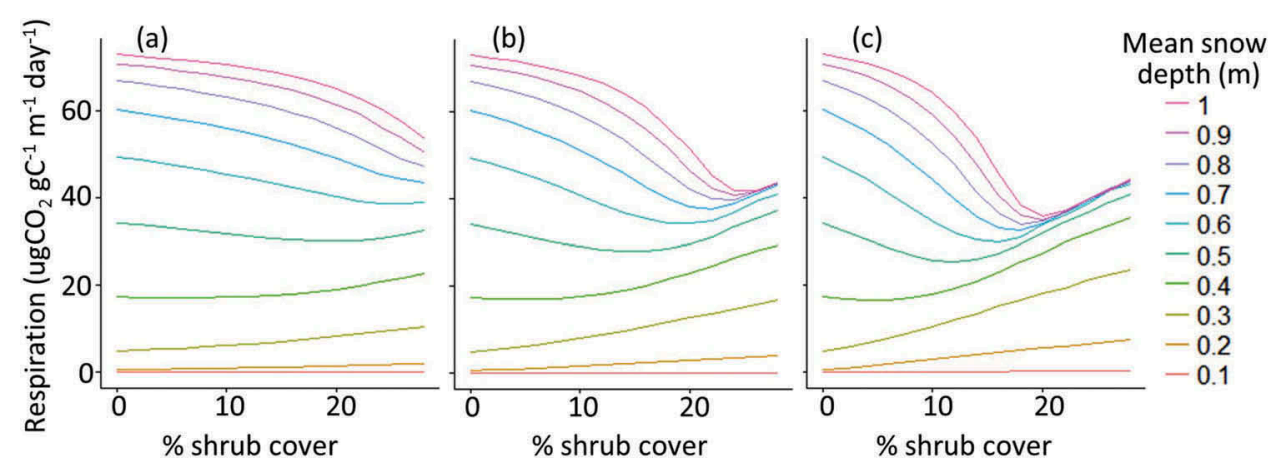

Figure 2. Soil respiration summed across the entire simulated landscape for (a) weak, (b) moderate, and (c) strong levels of the windbreak effect. Density of shrub cover (x axis) varies between $0 \%$ and $30 \%$ of pixels, and mean snow depth (coloured curves) varies between $10 \mathrm{~cm}$ and $1 \mathrm{~m}$. 
on landscape-level respiration than vegetation structure, since the maximum and minimum respiration rates across all simulations were achieved for the same level of shrub coverage (0\%).

Mean end-of-winter snow depth in the Northern Brooks Range foothills currently fluctuates around the $40 \mathrm{~cm}$ threshold where increasing shrub cover reduces respiration (Stuefer et al. 2012). For winters with mean snow depth between $20 \mathrm{~cm}$ and $40 \mathrm{~cm}$, the simulations indicate that greater shrub cover positively impacts landscape-level soil respiration. However, snowfall is predicted to increase throughout the Arctic (Bintanja \& Selten 2014). As mean snow depths $40 \mathrm{~cm}$ or greater become more common, shrub expansion may provide a net negative feedback to wintertime soil temperatures and respiration on a landscape scale. Other temperature-dependent soil processes like nitrogen mineralization may follow similarly complex patterns in response to vegetation impacts on snow depth heterogeneity.

By design, these simulations represent a simplification of reality in order to outline the potential wintertime soil respiration responses to shrub expansion. This approach follows Rastetter's (2017) description of a generalized, mechanistic "model for understanding", which aims to characterize potential behaviours of a system by examining only the system's most basic processes. Therefore, excluded from the simulations are more complex processes like snowpack density and evolution, topography, shrub reproduction dynamics, litter chemistry feedbacks, and shrub-herbivore interactions, all of which are discussed in detail elsewhere (Liston et al. 2002; Essery \& Pomeroy 2004; Myers-Smith et al. 2011; Christie et al. 2015; McLaren et al. 2017). For example, wind-drifted snow deposited in open tussock areas tends to be finer-grained, denser and less insulative than snow deposited in shrubs, which forms large depth hoar crystals that increase insulative properties (Benson \& Sturm 1993). This snowpack structural variability is not specified in the simulations. Despite (or perhaps because of) such simplifications, the simulations suggest useful avenues of future empirical study to better understand wintertime impacts of shrub expansion.

In designing future experiments, it is recommended that plots contain variable shrub densities and sizes, rather than binary states of shrub presence/absence. As shown in the simulations for snow depths of $40 \mathrm{~cm}$ or greater, soil respiration response to shrub cover is not linear, and a presence/absence study would fail to capture this complexity. Additionally, experimental plots should be larger than $1 \mathrm{~m}^{2}$, since small scales do not account for shrub effects that extend multiple metres beyond the shrub itself. Larger plots could also improve our understanding of the controls on the strength of the windbreak effect. These guidelines should allow investigators to measure response variables and make inference about shrub-altered ecosystem processes at a landscapescale. Such measurements and inferences may then be incorporated into larger-scale Earth system models (e.g., Zhang et al. 2013) with greater accuracy.

\section{Conclusion}

These simulation results suggest that there is no overarching positive relationship between shrub density and wintertime soil respiration on a landscape scale. Rather, the relationship between these two variables depends strongly on mean snow depth and the strength of the windbreak effect. The variability in simulation outcomes challenges assumptions about the impact of shrub expansion on tundra carbon balance. These simulations can generate a range of hypotheses to be tested by experimental manipulations, ultimately leading to improved representation of shrub expansion dynamics in Earth system models.

\section{Acknowledgements}

I thank Dr Ken Tape, Dr Patrick Sullivan and two anonymous reviewers for their thoughtful feedback on the ideas presented here. This project was inspired by discussions in the 2017 Arctic Winter Ecology course at the University Centre in Svalbard, led by Dr Ingibjörg Svala Jónsdóttir.

\section{Disclosure statement}

No potential conflict of interest was reported by the author.

\section{Funding}

Financial support was generously provided by the National Science Foundation Graduate Research Fellowships Program (grant no. 00039202) and the University of Minnesota Department of Ecology, Evolution, and Behavior; National Science Foundation (00039202).

\section{ORCID}

Daniel Ackerman (D) http://orcid.org/0000-0002-9305-4184

\section{References}

Baptist F., Yoccoz N.G. \& Choler P. 2010. Direct and indirect control by snow cover over decomposit ion in alpine tundra along a snowmelt gradient. Plant and Soil 328, 397-410.

Benson C.S. \& Sturm M. 1993. Structure and wind transport of seasonal snow on the Arctic slope of Alaska. Annals of Glaciology 18, 261-267. 
Bintanja R. \& Selten F.M. 2014. Future increases in Arctic precipitation linked to local evaporation and sea-ice retreat. Nature 509, 479.

Blok D., Elberling B. \& Michelsen A. 2016. Initial stages of tundra shrub litter decomposition may be accelerated by deeper winter snow but slowed down by spring warming. Ecosystems 19, 155-169.

Bueno C.G., Williamson S.N., Barrio I.C., Helgadóttir Á. \& Hik D.S. 2016. Moss mediates the influence of shrub species on soil properties and processes in alpine tundra. PLoS One 11, e0164143, doi: 10.1371/journal.pone.0164143.

Christie K.S., Bryant J.P., Gough L., Ravolainen V.T., Ruess R.W. \& Tape K.D. 2015. The role of vertebrate herbivores in regulating shrub expansion in the Arctic: a synthesis. BioScience 65, 1123-1133.

Essery R. \& Pomeroy J. 2004. Vegetation and topographic control of wind-blown snow distributions in distributed and aggregated simulations for an Arctic tundra basin. Journal of Hydrometeorology 5, 735-744.

Fahnestock J.T., Jones M.H. \& Welker J.M. 1999. Wintertime $\mathrm{CO}_{2}$ efflux from Arctic soils: implications for annual carbon budgets. Global Biogeochemical Cycles $13,775-779$.

Ge Y. \& Gong G. 2010. Land surface insulation response to snow depth variability. Journal of Geophysical ResearchAtmospheres 115, article no. 08107, doi: 10.1029/ 2009JD012798.

Grogan P. \& Jonasson S. 2006. Ecosystem $\mathrm{CO}_{2}$ production during winter in a Swedish Subarctic region: the relative importance of climate and vegetation type. Global Change Biology 12, 1479-1495.

Hallinger M., Manthey M. \& Wilmking M. 2010. Establishing a missing link: warm summers and winter snow cover promote shrub expansion into alpine tundra in Scandinavia. New Phytologist 186, 890-899.

Hobbie S.E. \& Chapin F.S. III. 1996. Winter regulation of tundra litter carbon and nitrogen dynamics. Biogeochemistry 35, 327-338.

Hugelius G., Strauss J., Zubrzycki S., Harden J.W., Schuur E., Ping C.L., Schirrmeister L., Grosse G., Michaelson G. J., Koven C.D. \& O’Donnell J.A. 2014. Estimated stocks of circumpolar permafrost carbon with quantified uncertainty ranges and identified data gaps. Biogeosciences 11, 6573-6593.

Liston G.E., Mcfadden J.P., Sturm M. \& Pielke R.A. 2002. Modelled changes in Arctic tundra snow, energy and moisture fluxes due to increased shrubs. Global Change Biology 8, 17-32.

McLaren J.R., Buckeridge K.M., Weg M.J., Shaver G.R., Schimel J.P. \& Gough L. 2017. Shrub encroachment in Arctic tundra: Betula nana effects on above- and belowground litter decomposition. Ecology 98, 1361-1376.

Mikan C.J., Schimel J.P. \& Doyle A.P. 2002. Temperature controls of microbial respiration in Arctic tundra soils above and below freezing. Soil Biology and Biochemistry 34, 1785-1795.

Morgner E., Elberling B., Strebel D. \& Cooper E.J. 2010. The importance of winter in annual ecosystem respiration in the High Arctic: effects of snow depth in two vegetation types. Polar Research 29, 58-74.

Myers-Smith I.H., Forbes B.C., Wilmking M., Hallinger M., Lantz T., Blok D., Tape K.D., Macias-Fauria M., SassKlaassen U., Lévesque E. \& Boudreau S. 2011. Shrub expansion in tundra ecosystems: dynamics, impacts and research priorities. Environmental Research Letters 6, 045509, doi: 10.1088/1748-9326/6/4/045509.
Myers-Smith I.H. \& Hik D.S. 2013. Shrub canopies influence soil temperatures but not nutrient dynamics: an experimental test of tundra snow-shrub interactions. Ecology and Evolution 3, 3683-3700.

Natali S.M., Schuur E.A. \& Rubin R.L. 2012. Increased plant productivity in Alaskan tundra as a result of experimental warming of soil and permafrost. Journal of Ecology 100, 488-498.

Nauta A.L., Heijmans M.M., Blok D., Limpens J., Elberling B., Gallagher A., Li B., Petrov R.E., Maximov T.C., Van Huissteden J. \& Berendse F. 2015. Permafrost collapse after shrub removal shifts tundra ecosystem to a methane source. Nature Climate Change 5, 67-70.

Nobrega S. \& Grogan P. 2007. Deeper snow enhances winter respiration from both plant-associated and bulk soil carbon pools in birch hummock tundra. Ecosystems 10, 419-431.

Oechel W.C., Laskowski C.A., Burba G., Gioli B. \& Kalhori A.A. 2014. Annual patterns and budget of $\mathrm{CO}_{2}$ flux in an Arctic tussock tundra ecosystem. Journal of Geophysical Research-Biogeosciences 119, 323-339.

Paradis M., Lévesque E. \& Boudreau S. 2016. Greater effect of increasing shrub height on winter versus summer soil temperature. Environmental Research Letters 11, 085005, doi: 10.1088/1748-9326/11/8/085005.

R Core Team. 2016. R: a language and environment for statistical computing. Vienna: $\mathrm{R}$ Foundation for Statistical Computing.

Rastetter E.B. 2017. Modeling for understanding v. modeling for numbers. Ecosystems 20, 215-221.

Rogers M.C., Sullivan P.F. \& Welker J.M. 2011. Evidence of nonlinearity in the response of net ecosystem $\mathrm{CO}_{2}$ exchange to increasing levels of winter snow depth in the High Arctic of northwest Greenland. Arctic, Antarctic, and Alpine Research 43, 95-106.

Schimel J.P., Bilbrough C. \& Welker J.M. 2004. Increased snow depth affects microbial activity and nitrogen mineralization in two Arctic tundra communities. Soil Biology and Biochemistry 36, 217-227.

Stieglitz M., Ducharne A., Koster R. \& Suarez M. 2001. The impact of detailed snow physics on the simulation of snow cover and subsurface thermodynamics at continental scales. Journal of Hydrometeorology 2, 228-242.

Stuefer S.L., Homan J.W., Youcha E.K., Kane D.L. \& Gieck R.E. 2012. Snow survey data for the central north slope watersheds: spring 2012. Report INE/WERC 12.22. Fairbanks, AK: Water and Environmental Research Center, University of Alaska Fairbanks.

Sturm M., Holmgren J., McFadden J.P., Liston G.E., Chapin F.S. III \& Racine C.H. 2001. Snow-shrub interactions in Arctic tundra: a hypothesis with climatic implications. Journal of Climate 14, 336-344.

Sturm M., Schimel J., Michaelson G., Welker J.M., Oberbauer S.F., Liston G.E., Fahnestock J. \& Romanovsky V.E. 2005. Winter biological processes could help convert Arctic tundra to shrubland. AIBS Bulletin 55, 17-26.

Tape K., Sturm M. \& Racine C. 2006. The evidence for shrub expansion in northern Alaska and the Pan-Arctic. Global Change Biology 12, 686-702.

Taras B., Sturm M. \& Liston G.E. 2002. Snow-ground interface temperatures in the Kuparuk River Basin, Arctic Alaska: measurements and model. Journal of Hydrometeorology 3, 377-394.

Tarnocai C., Canadell J.G., Schuur E.A.G., Kuhry P., Mazhitova G. \& Zimov S. 2009. Soil organic carbon pools in the northern circumpolar permafrost region. 
Global Biogeochemical Cycles 23, GB2023, doi: 10.1029/ 2008 GB003327.

Walker D.A., Raynolds M.K., Daniëls F.J., Einarsson E., Elvebakk A., Gould W.A., Katenin A.E., Kholod S.S., Markon C.J., Melnikov E.S. \& Moskalenko N.G. 2005. The circumpolar Arctic vegetation map. Journal of Vegetation Science 16, 267-282.

Walker M.D., Walker D.A., Welker J.M., Arft A.M., Bardsley T., Brooks P.D., Fahnestock J.T., Jones M.H., Losleben M., Parsons A.N. \& Seastedt T.R. 1999. Longterm experimental manipulation of winter snow regime and summer temperature in Arctic and alpine tundra. Hydrological Processes 13, 2315-2330.

Zhang T. 2005. Influence of the seasonal snow cover on the ground thermal regime: an overview. Reviews of Geophysics 43, RG4002, doi: 10.1029/2004RG000157.

Zhang W., Miller P.A., Smith B., Wania R., Koenigk T. \& Döscher R. 2013. Tundra shrubification and tree-line advance amplify Arctic climate warming: results from an individual-based dynamic vegetation model. Environmental Research Letters 8, 034023, doi: 10.1088/ 1748-9326/8/3/034023. 